\title{
SISTEM INFORMASI PENJUALAN BARANG DENGAN METODE REGRESI LINEAR BERGANDA DALAM PREDIKSI PENDAPATAN PERUSAHAAN
}

\author{
Yanti Aryani ${ }^{1)}$,Dudih Gustian ${ }^{2)}$ \\ ${ }^{1,2)}$ Program Studi Sistem Informasi, Universitas Nusa Putra Sukabumi \\ Jl. Raya Cibolang No. 21 Sukabumi, Jawa Barat, 43152 Indonesia, Tlp. 0266210594 \\ ${ }^{1)}$ yantiaryani6@gmail.com, ${ }^{2)}$ dudih@nusaputra.ac.id \\ *Korespondensi : yantiaryani6@gmail.com
}

\begin{abstract}
ABSTRAK
Prediksi pendapatan karena merupakan factor penting yang menentukan kelancaran penjualan bagi usahanya karena digunakan sebagai acuan untuk melihat pendapatan di periode berikutnya. Permasalahan yang di hadapi perusahaan pencatatan, pengolahan barang, jumlah barang, data transaksi penjualan dan pembelian yang dilakukan masih bersifat manual belum terdokumentasi secara baik. Penelitian ini bertujuan untuk mengetahui variabel manakah yang berpengaruh terhadap pendapatan. Dalam hal metode yang digunakan adalah Regresi Linear Berganda dengan bantuan perhitungan aplikasi SPSS versi 21 di peroleh hasil persamaan regresi $Y$ $=11257,187-3,427(X 1)+12,501(X 2)-2,076(X 3)$ dengan nilai ( Uji T, Uji F dan R2) dengan mengambil nilai sig < 0,05 . hasil dari pengujian hipotesis Uji T secara individual dapat disimpulkan bahwa variabel X1,X2 dan X3 berpengaruh terhadap pendapatan. Hasil dari Uji $F$ dengan taraf sig $<0,05$ dapat disimpulkan bahwa variabel $X 1, X 2$ dan X3 secara bersama-sama berpengaruh terhadap pendapatan perusahan. Hasil dari koefisien determinasi (R2) di peroleh nilai yang sangat tingggi yaitu 1,000. Hal ini dapat dikatakan Semakin kecil nilai koefisien determinasi ( $R$ square), maka ini artinya pengaruh variabel bebas terhadap variabel terikat semakin lemah. Sebaliknya, jika nilai $R$ Square semakin mendekati 1, maka pengaruh tersebut akan semakin kuat.
\end{abstract}

Kata kunci : Prediksi, Regresi Linear Berganda, Pendapatan, CV. Kaca Mobil Nugraha

\begin{abstract}
Income prediction because it is an important factor that determines the smoothness of sales for its business because it is used as a reference to see revenue in the next period. The problems faced by companies recording, processing goods, the amount of goods, data on sales and purchase transactions that are carried out are still manual are not well documented. This study aims to determine which variables influence income. In terms of the method used is Multiple Linear Regression with the help of SPSS version 21 application calculations obtained the regression equation $Y=11257,187-3,427(X 1)+12,501(X 2)-2,076(X 3)$ with the value (T test, $F$ test and $R 2)$ by taking the sig value $<0.05$. the results of testing the $T$ Test hypothesis individually can be concluded that the variables X1, X2 and X3 affect income. The results of Test F with sig level <0.05 can be concluded that the variables X1, X2 and X3 together affect the company's income. The result of the coefficient of determination (R2) is obtained at a very high value of 1,000. It can be said that the smaller the coefficient of determination ( $R$ square), then this means that the effect of the independent variable on the dependent variable is increasingly weak. Conversely, if the value of $R$ Square gets closer to 1, then the effect will be stronger.
\end{abstract}

Keyword : Predictions, Multiple Linear Regression, Income, CV. Kaca Mobil Nugraha

\section{PENDAHULUAN}

Pendapatan merupakan factor penting yang dapat menentukan kelancaran usahanya. Namun dapat diartikan juga sebagai banyaknya penerimaan dari penjualan produk atau jasa kepada pelanggan. Apabila banyaknya jumlah barang terjual maka akan semakin besar pula penghasilan atau pendapatan yang diperoleh perusahaan pada periode tertentu, Pendapatan pada perusahaan CV. Kaca Mobil Nugraha terbilang tidak menentu, tinggi rendahnya pendapatan tergantung dalam mengelola setiap transaksi yang ada, karena tidak tepatnya perusahaan dalam mengambil keputusan pada jumlah pembelian suatu barang, di setiap periodenya. 
Berikut adalah tingkat pendapatan, berdasarkan data pendapatan, pembelian barang, dan banyaknya jumlah barang yang terjual kaca spion dan kaca mobil. Untuk lebih jelasnya dapat dilihat pada gambar di bawah ini :

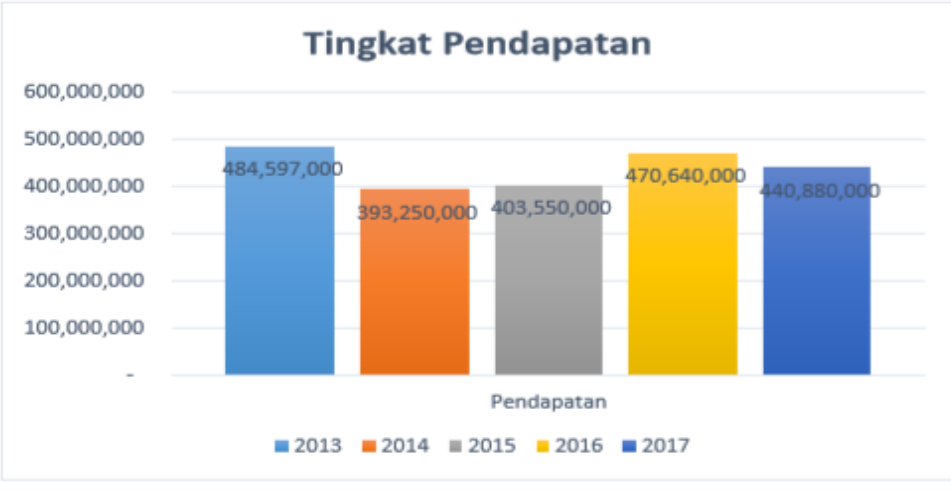

Gambar 1. Data hasil pendapatan

Dari grafik diatas menunjukan, pada tahun 2013 pendapatan mencapai 484,597,000. dan pada tahun 2014 mengalami penurunan dengan pendapatan 393,250,000, selanjutnya tahun 2015 dan 2016 pendapatan mengalami peningkatan dengan masing - masing pendapatan 403,550,000 dan 470,640,000, dan mengalami penurunan pendapatan pada tahun 2017 dengan besar pendapatan 440,880,000. Jadi, dapat disimpulkan bahwa pendapatan pada CV. Kaca mobil Nugraha tidak stabil.

Selama ini perusahaan secara tidak langsung selalu memprediksi penjualan yang akan datang. Akan tetapi prediksi ini selalu kurang tepat karena hanya melihat perkiraan berdasarkan penjualan yang telah terjadi yang dilakukan secara manual yang ditangani oleh seorang admin pada perusahaan tersebut. Pencatatan dan pengolahan data barang, jumlah dan harga barang, serta data transaksi penjualan dan pembelian yang dilakukan masih bersifat manual belum terdokumentasi secara baik, sehingga hal tersebut tidak dapat memperoleh informasi dan sangat memperlambat jalannya kegiatan pekerjaan yang ada di CV. Kaca Mobil Nugraha. Hal semacam ini perlu dicarikan penyelesaiannya dengan dibangunnya sebuah sistem yang bisa memenuhi dari apa yang dibutuhkan, agar segala aktivitas pekerjaan yang ada berjalan dengan waktu yang lebih cepat dari sebelumnya yang akan berpengaruh juga terhadap pendapatan pada perusahaan.

Prediksi pendapatan ini sangat berguna untuk menentukan atau mengetahui berapa banyak tingkat pendapatan pada periode selanjutnya. Prediksi ini juga dapat mengetahui variabel mana sajakah yang sangat berpengarh terhadap pendapatan pada penjualan perusahaan pada tiap periodenya. Perusahaan yang mampu memprediksi dengan tepat umumnya akan lebih siap dalam mengambil keputusan, dengan berkembangnya perusahaan ini, maka banyak pula permasalahan yang di hadapi terutama perusahaan harus selalu cermat dalam memprediksi situasi keadaan. Untuk menghasilkan prediksi yang tepat tentu saja dibutuhkan kecermatan dan ketelitian.

Dalam hal ini memprediksi pendapatan terhadap penjualan barang di masa mendatang dengan melihat data penjualan yang diperoleh dari data yang telah ada sebelumnya agar pengolahan data lebih akurat yaitudari tahun 2013-2017 yang dilihat pada transaksi penjualan yaitu hasil pendapatan, pembelian barang, dan jumlah barang yang terjual. Dengan adanya system komputerisasi, maka akan dibuat program bantu prediksi penjualan untuk menyelesaikan masalah yang di hadapi perusahaan ini. Sebelum penelitian ini dilakukan pemilihan dan penggunaan metode yang tepat maka dapat membantu keberhasilan perusahaan dalam bentuk pendapatan yang didapatkan. namun banyak metode yang dapat di ginakan dalam proses peramalan atau prediksi di antaranya adalah metode Jarignan Syaraf Tiruan, SVM dan Linear Regresi.

Pada penelitian sebelumnya yaitu dengan metode ANFIS telah diterapkan dalam analisis data runtun waktu yang dibandingkan dengan metode ARIMA [1]. Hasilnya, metode ANFIS lebih baik dari ARIMA. ANFIS juga telah digunakan untuk memprediksi laba atas harga saham Indeks Bursa Efek Istanbul (ISE) [2]. ANFIS berhasil memperkirakan monthly return ISE National 100 Index dengan tingkat 
akurasi 98,3\%. ANFIS juga telah digunakan untuk peramalan beban listrik jangka pendek yang dibandingkan dengan hasil peramalan menggunakan metode Artificial Neural Network (ANN) [3]. Penelitian sebelumnya menggambarkan bahwa metode SVM adalah metode yang berlandaskan pada teori pembelajaran statistic dan memberi hasil yang menjanjikan akan lebih baik dibanding metode lain. SVM bekerja juga dengan baik terhadap data yang berdimensi tinggi dengan menggunakan teknik kernel [4]. Metode SVM tidak menghasilkan hasil yang akurat ketika banyak fitur yang tidak relevan, tidak semua fitur diperlukan dalam proses. Seleksi fitur bekerja secara langsung mengurangi jumlah fitur dan memilih fitur yang benar-benar memberikan informasi,jumlahfitur berkurang secara signifikandan masalahoverfitting teratasi. Metode SVM memberikan kinerja yang efektif, ketika fitur yang tidak relevan dihilangkan [5]. Sedangkan metode Regresi Linear berdasarkan hasil penelitian terdahulu dapat mempermudah pemilik perusahaan untuk melihat hasil prediksi pendapatan, meminimalisir kerugian, memberikan informasi yang cepat dan akurat tentang prediksi pendapatan [6].

Berdasarkan perbandingan serta pertimbangan metode diatas, maka penelitian ini menggunakan metode Linier Regresi Berganda dalam memprediksi pendapatan Perusahaan karena memiliki kelebihan yang tidak ada dalam metode yang lain.

Tujuan dari penelitian ini yaitu dapat memberikan informasi dan memprediksi pendapatan pada periode selanjutnya. Selain itu, dengan adanya penelitian prediksi pendapatan ini diharapkan perusahaan dapat mengetahui kebutuhan apa saja yang diperlurkan untuk mencapai target di tahun berikutnya, serta dapat mengetahui ketepatan pada penjualan sesuai dengan hasil prediksi pendapatan tersebut, dan membantu perusahaan untuk mengontrol setiap transaksi penjualan barang dengan hasil yang bisa membantu memudahkan perhitungan pendapatan pada perusahaan. Dalam hal ini penulis menggunakan metode Linier Regresi Berganda dengan perhitungan SPSS Versi 21, agar dapat membantu perusahaan untuk mengetahui seberapa besar pengaruh variabel yang di teliti yaitu pembelian barang dan jumlah barang terjual terhadap pendapatan pada CV. Kaca Mobil Nugraha sebagai acuan perusahaan pada periode selanjutnya.

\section{TINJAUAN PUSTAKA}

Penelitian oleh Ratih Dewanti dan Ginda Sihombing (2012) yang berjudul "Analisis Pendapatan Usaha Peternakan Ayam Buras (Studi Kasus di Kecamatan Tegalombo, Kabupaten Pacitan). Penelitian ini bertujuan untuk mengetahui besarnya pendapatan yang diperoleh peternak ayam buras dan pengaruh faktor-faktor produksi terhadap pendapatan usaha peternakan ayam buras di Kecamatan Tegalombo Kabupaten Pacitan. Penelitian dilaksanakan di Desa Kemuning, Desa Tegalombo dan Desa Tahunan mulai tanggal 3 Januari sampai 4 Februari 2011. Metode yang digunakan dalam penelitian adalah metode survei dengan wawancara langsung kepada 30 peternak dan pengambilan lokasi dilakukan secara sengaja (purposive sampling). Data yang dikumpulkan ditabulasi kemudian dianalisis untuk mengetahui pendapatan. Analisis data dilakukan dengan menggunakan fungsi keuntungan dengan teknik Unit Output Price Cobb-Douglas Profit Function (OUP-CDPF) melalui analisis Regresi Berganda (alat bantu software Econometric Views/Eviews) dan dilanjutkan dengan uji $\mathrm{F}$ dan uji t. Hasil penelitian menunjukkan bahwa rata-rata pendapatan bersih dari penjualan ayam buras 89 ekor, feses dan telur yaitu Rp. 1.383.358,10 per tahun/peternak. Berdasarkan analisis Regresi Linear Berganda diperoleh persamaan $\hat{\mathrm{Y}}=20,947+0,620 \mathrm{X} 1+0,003 \mathrm{X} 20,996 \mathrm{X} 3-0,869 \mathrm{X} 4-0,015 \mathrm{X} 5+0,845 \mathrm{X} 6$. Nilai koefisien determinasi $\left(\mathrm{R}^{2}\right)$ sebesar 0,646 berarti pendapatan ayam buras mampu dijelaskan oleh biaya pembelian ayam, jagung, dedak, obat/vitamin, tenaga kerja dan listrik sebesar 64,6\%. Sedangkan sisanya sebesar 35,4\% dipengaruhi oleh variabel-variabel di luar yang diteliti. Pada uji F, variabel independen (biaya pembelian ayam, jagung, dedak, obat/vitamin, tenaga kerja, dan listrik) berpengaruh secara bersama terhadap variabel dependen dengan tingkat signifikan 0,05. Berdasarkan uji T faktor biaya pendapatan dipengaruhi oleh pembelian ayam dan biaya listrik sedangkan biaya lainnya (biaya jagung, obat/vitamin, dan tenaga kerja) tidak berpengaruh terhadap pendapatan usaha peternakan ayam buras di Kecamatan Tegalombo, Kabupaten Pacitan [7].

Penelitian yang dilakukan oleh Resti Hutami dengan Erna Zuni Astuti (2016) yang berjudul "Implementasi Metode K-Nearest Neighbor untuk Prediksi Penjualan Furniture Pada Cv. Octo Agung 
Jepara". Penelitian ini menggunakan Metode K-Nearest Neighbor prediksi data penjualan furniture pada $\mathrm{CV}$. Octo Agung Jepara, dimana mampu menyelesaikan kasus prediksi penjualan dengan tingkat error atau MSE sebesar 6 persen dan akurasi 94 persen [8].

Penelitian yang selanjutnya di lakukan oleh Muhamad Muslih, Nunik Destria Arianti, Ahmad Husen, Dudih Gustian, Samsul Pahmi, Ayunis Rizkia Pratamie, Nasrudin, SantiAlawiyah, Ria Dewi Hudayani (2017). Dengan parameter yang digunakan yaitu fasilitas kampus, pengaruh luar, informasi kampus kepada siswa, akademik, keuangan, kemahasiswaan dan pengaruh dengan strategi pemasaran. Penelitian ini menggunakan metode Regresi Linear yang menghasilkan keputusan yang akurat, terutama untuk mengetahui sejauh mana tingkat mahasiswa baru yang masuk ke STT XYZ pada tahun akademik berikutnya, pada tahun akademik 2017/2018 [9].

\section{METODOLOGI PENELITIAN}

\subsection{Variabel Penelitian dan Sampel Penelitian}

\subsubsection{Variabel Penelitian}

Dalam penelitian ini menggunakan dua jenis variabel yaitu variabel bebas (independent) dan variabel terikat (dependent).

\subsubsection{Variabel Bebas (Independent)}

Tabel 1. Variabel Bebas

\begin{tabular}{|c|c|c|c|c|}
\hline No & Tahun & $\begin{array}{c}\text { pembelian_barang } \\
\left(\mathbf{X}_{\mathbf{1}}\right)\end{array}$ & $\begin{array}{c}\text { jumlah_kacaspion } \\
\left(\mathbf{X}_{2}\right)\end{array}$ & $\begin{array}{c}\text { jumlah_kacamobil } \\
\left(\mathbf{X}_{\mathbf{2}}\right)\end{array}$ \\
\hline 1 & 2013 & $180,400,000$ & 119 & 830 \\
\hline 2 & 2014 & $191,100,000$ & 64 & 760 \\
\hline 3 & 2015 & $202,500,000$ & 90 & 679 \\
\hline 4 & 2016 & $175,000,000$ & 49 & 560 \\
\hline 5 & 2017 & $192,060,000$ & 125 & 876 \\
\hline
\end{tabular}

Variabel bebas adalah variabel yang mempengaruhi atau menjelaskan variable yang lain [11]. Variabel bebas dalam penelitian ini pembelian barang, dan jumlah barang terjual.

\subsubsection{Variabel Terikat}

Tabel 2. Variabel Terikat

\begin{tabular}{|c|c|c|}
\hline No & Tahun & Pendapatan \\
\hline 1 & 2013 & $484,597,000$ \\
\hline 2 & 2014 & $393,250,000$ \\
\hline 3 & 2015 & $403,550,000$ \\
\hline 4 & 2016 & $470,640,000$ \\
\hline 5 & 2017 & $440,880,000$ \\
\hline
\end{tabular}

Variabel yang dijelaskan atau dipengaruhi oleh variable independent. Variabel terikat dalam penelitian ini adalah hasil pendapatan.

\subsection{Metode Pengumpulan Data}

\subsubsection{Dokumentasi}

Metode dokumentasi adalah cara pengumpulan data melalui peninggalan tertulis terutama berupa arsip-arsip dan termasuk juga buku mengenai pendapat yang berhubungan dengan masalah penyelidikan. Pada penelitian ini data-data yang terkumpul sebagai objek didapat dari dokumentasi data penjualan perusahaan dan pada penelitian terdahulu. Data yang diperoleh dari dokumentasi penjualan tahun 2013 sampai 2017.

\subsubsection{Metode Wawancara}

Wawancara Metode pengumpulan data dengan cara mengajukan pertanyaan secara lisan kepada pihak yang bersangkutan.Proses wawancara dan survey dilakukan secara langsung, dengan jalan 
pewancara memberikan pertanyaan-pertanyaan seputar sistem kepada responden, dan responden kemudian memberikan jawaban dan data yang berkaitan dengan pertanyaan kepada pewancara.

\subsection{Metode Pengolahan Data}

Dalam penelitian ini tahap pengolahan data yang digunakan adalah sebagai berikut :

\subsubsection{Alat Bantu dan Bahan Untuk Pengolahan Data}

Alat yang diperlukan dalam pengolahan data ini memerlukan beberapa alat dari perangkat keras (Hardware) dan alat yang berupa perangkat lunak (software) seperti program-program aplikasi untuk mempermudah proses perhitungan maupun grafik-grafik serta proses menganalisa data.

\subsubsection{Alat Bantu Untuk Mengolah Data}

Pembuatan dan pengembangan aplikasi yang digunakan oleh peneliti menggunakan :

1. Membutuhkan sebuah program demi melancarkan perhitungan yang akurat seperti program SPSS maupun program dari office seperti MS. Excel serta menggunakan PHP Mysql untuk perancangan sebuah aplikasi yang akan dibuat.

2. Laptop yang digunakan peneliti untuk melakukan implementasi dan uji coba aplikasi prediksi pendapatan penjualan.

\subsection{Analisis Kebutuhan SistemDan Perancangan Sistem Berbasis Web}

Perancangan sistem menggunakan Unified Modeling Language (UML) dan perancangan database. Use Case diagram (diagram use case) adalah diagram yang menyajikan interaksi antara use case dan actor. Dimana actor dapat berupa orang, peralatan atau sistem lain yang berinteraksi dengan sistem yang sedang dibangun. Use case menggambarkan fungsionalitas sistem atau persyaratan-persyaratan yang harus dipenuhi sistem dari pandangan pemakai. Dalam system ini ada 2 aktor use case yaitu use case sebagai admin dan customer, serta class diagram. Berikut ini perancangan sistem informasi penjualan barang :

\subsubsection{Use Case Admin}

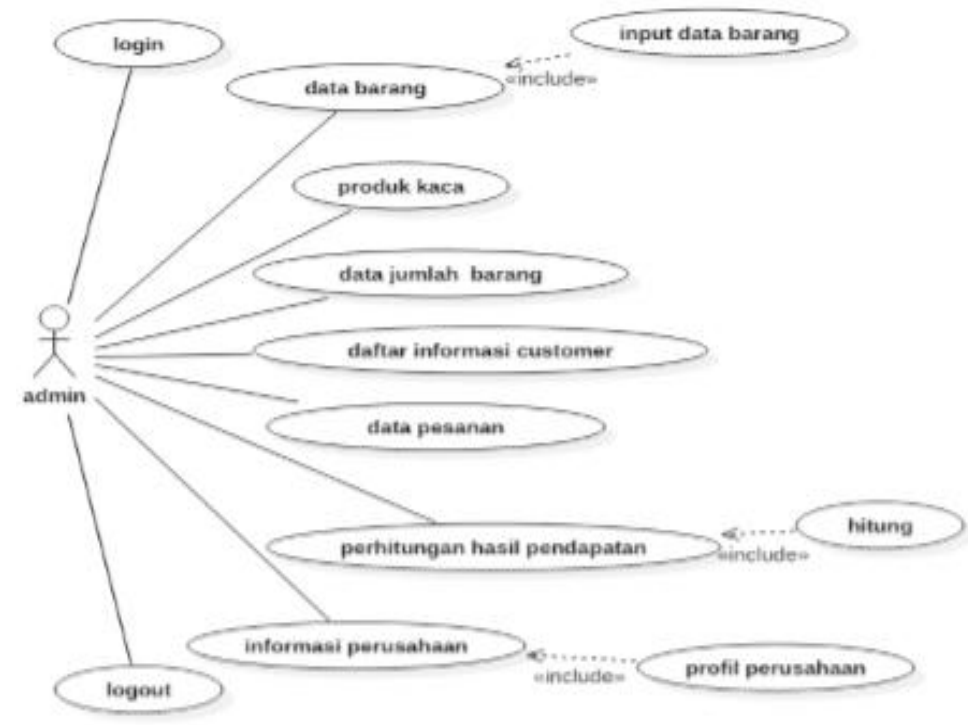

Gambar 2. Use case admin

Pada gambar use case admin di atas, admin melakukan login serta menginput segala transaksi penjualan yang ada seperti, menginput data barang, prodk kaca, jumlah barang, informasi customer, data pesanan, perhitungan hasil pendapatan, informasi perusahaan dan melakukkan logout terhadap sistem. 


\subsubsection{Use Case Customer}

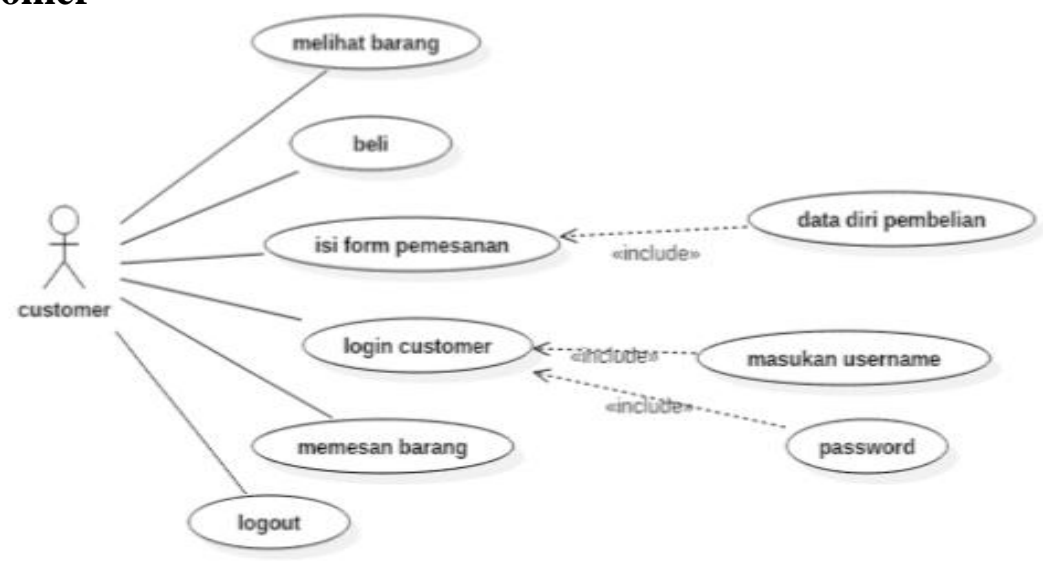

Gambar 3. Use case customer

Pada gambar Use case customer diatas, dimana yang menjadi actor adalah sebagai customer. Customer dapat melihat barang terlebih dahulu, lalu jika ada barang yang sesuai bisa melakukakn pembelian. Namun sebelum melakukan pembelian customer harus mengisi form pemesanan terlebih dahulu atau mengisi data diri pemelian sebelum masuk dan untuk melakukan login sebagai customer. Setelah itu customer bisa masuk login dengan memasukkan username dan password yang sudah di berikan oleh system atau admin. Lalu baru customer bisa memesan barang sesuai apa yang di inginkan dan bisa melakukan logout kembali.

\subsubsection{Class Diagram}

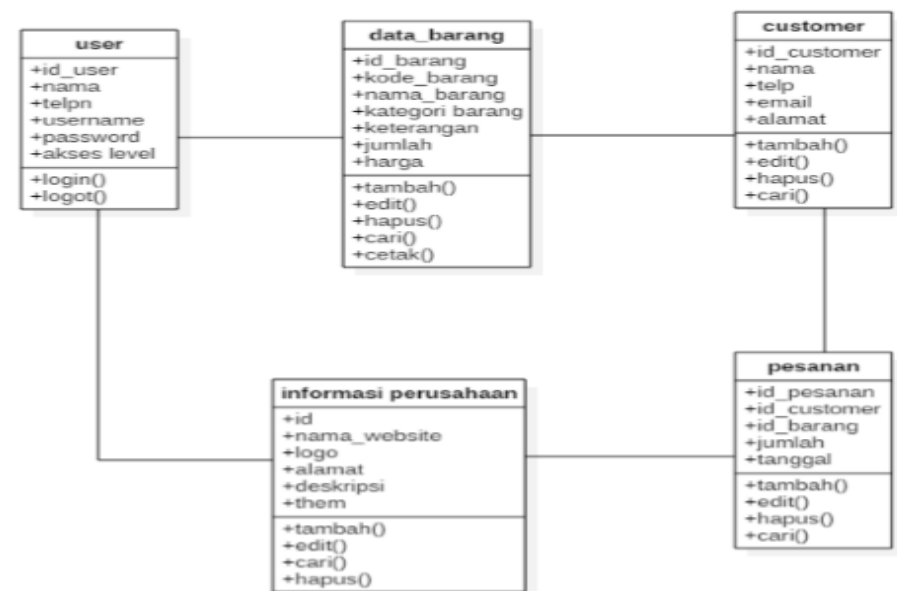

Gambar 4. Class diagram

Pada gambar Class Diagram diatas, menggambarkan struktur statis class di dalam sistem. Class merepresentasikan sesuatu yang ditangani oleh sistem. Dengan melihat karakteristik sistem pemasaran produk dari bagian penjualan beserta proses-proses yang terjadi, maka dapat dibuat class diagram. Berikut ini adalah penggambaran class diagram yang diusulkan.

\subsection{Implementasi Metode Regresi Linear Berganda}

Adapun tujuan dari metode Regresi Linear Berganda yaitu :

1) Metode Regresi Linear Berganda bertujuan untuk mengetahui ada atau tidaknya pengaruh dua atau lebih variabel bebas $(\mathrm{X})$ terhadap variabel terikat (Y).

2) Uji t untuk bertujuan untuk mengetahui ada atau tidaknya pengaruh parsial (sendiri ) yang diberikan variabel bebas $(\mathrm{X})$ terhadap variabel terikat $(\mathrm{Y})$.

3) Uji F bertujuan untuk mengetahui ada atau tidaknya pengaruh-pengaruh simltan ( bersama-sama) yang diberikan variabel bebas $(\mathrm{X})$ terhadap variabel terikat $(\mathrm{Y})$. 
4) Uji R2 (Koefisien determinasi) berfungsi untuk mengetahui berapa persen pengaruh yang di berikan, variabel X secara simultan terhadap variabel Y.

Model regresi ini dipilih untuk memprediksikan nilai dari variabel dependen apabila nilai variabel independen mengalami kenaikan atau penurunan dan untuk mengetahui arah hubungan antara variabel independen yaitu pengaruh pendapatan penjualan, serta pengeluaran dan umum dengan variabel dependen yaitu hasil pendapatan apakah positif atau negatif.

Analisis regresi linier berganda digunakan untuk mengetahui seberapa besar pengaruh hubungan variabel (X1), (X2), dan (X3) terhadap variabel dependen hasil pendapatan (Y). Persamaan regresi yang dipakai adalah sebagai berikut [12].

$\mathrm{Y}=\mathrm{a}+\beta 1 \mathrm{X} 1+\beta 2 \mathrm{X} 2+\beta 3 \mathrm{X} 3 \ldots \ldots$ Keterangan :

$\mathrm{Y}=$ Jumlah pendapatan

$\mathrm{a}=$ Nilai konstanta

$\mathrm{X} 1$ = Koefisien regresi dari variabel X1 (Pembelian barang)

$\mathrm{X} 2$ = Koefisien regresi dari variabel X2 (jumlah barang terjual kaca spion)

X3 = Koefisien regresi dari variabel X3 (jumlah barang terjual kaca mobil ) .

\subsection{Hasil Penelitian}

\section{HASIL DAN PEMBAHASAN}

Hasil penelitian berisi pengolahan data menggunakan metode regresi linear berganda dengan bantuan yang sudah ada yaitu aplikasi SPSS versi 21. Implementasi system penjualan barang serta system untuk perhitungan nominal penjualan guna mendapatkan informasi tentang seberapa besar pendapatan yang di peroleh pada CV. Kaca Mobil Nugraha. kemudian data hasil penjualan dimasukan secara komputerisasi dalam bentuk sistem perhitungan. Perancangan system yang akan dibangun dalam penelitian ini menggunakan bahasa pemograman PHP dan MySQL sebagai database. Pengelompokkan Data yang akan digunakan:

Tabel 3. Data Transaksi Hasil Penjualan

\begin{tabular}{|c|c|c|c|c|}
\hline Tahun & Pendapatan & pembelian_barang & $\begin{array}{c}\text { jumlah_kaca } \\
\text { spion }\end{array}$ & $\begin{array}{c}\text { jumlah_kaca } \\
\text { mobil }\end{array}$ \\
\hline 2013 & $484,597,000.00$ & $180,400,000.00$ & 119 & 830 \\
\hline 2014 & $393,250,000.00$ & $191,100,000.00$ & 64 & 760 \\
\hline 2015 & $403,550,000.00$ & $202,500,000.00$ & 90 & 679 \\
\hline 2016 & $470,640,000.00$ & $175,000,000.00$ & 49 & 560 \\
\hline 2017 & $440,880,000.00$ & $192,060,000.00$ & 125 & 876 \\
\hline
\end{tabular}

Pada tabel 3 merupakan tabel data transaksi hasil penjualan berisi tentang banyaknya pendapatan, pembelian, serta jumlah barang yang sudah terjual selama 5 tahun terakhir.

\subsection{Pengujian Hipotesis}

\subsubsection{Analisis Regresi Linear Berganda}

Analisis regresi linier berganda digunakan untuk menguji hipotesis pengaruh secara bersama-sama dan parsial antara variabel independen terhadap dependen. Berdasarkan estimasi regresi linier berganda dengan menggunakan program SPSS Versi 21. 


\subsubsection{Uji Hipotesis Secara Individual (Uji T)}

Tabel 4. Analisis Regresi Linear Berganda

Coefficients $^{\mathrm{a}}$

\begin{tabular}{l|l|r|r|r|r|}
\hline \multicolumn{1}{|c|}{ Model } & \multicolumn{2}{|c|}{$\begin{array}{c}\text { Unstandardized } \\
\text { Coefficients }\end{array}$} & $\begin{array}{c}\text { Standardized } \\
\text { Coefficients }\end{array}$ & \multicolumn{1}{c|}{ Sig. } & \\
\cline { 2 - 4 } & \multicolumn{1}{|c|}{ B } & Std. Error & \multicolumn{1}{c|}{ Beta } & & \\
\hline (Constant) & 11257.187 & 111.216 & & 101.219 & .006 \\
pembelian_baran & -3.427 & .058 & -.919 & -59.204 & .011 \\
g & & & & & \\
kaca_spion & 12.501 & .346 & 1.036 & 36.136 & .018 \\
kaca_mobil & -2.076 & .091 & -.650 & -22.710 & .028 \\
\hline
\end{tabular}

Hipotesis :

1. Jika nilai sig $<0,05$ atau $t$ hitung $>\mathrm{t}$ tabel, maka terdapat pengaruh variabel bebas $(\mathrm{X})$ terhadap varabel terikat (Y).

2. Jika nilai sig >0,05 atau t hitung $<\mathrm{t}$ tabel, maka tidak terdapat pengaruh variabel bebas $(\mathrm{X})$ terhadap varabel terikat (Y).

\subsubsection{Uji Hipotesis Secara Simultan (Uji F)}

Tabel 5. Analisis pengujian secara simultan uji F.

ANOVA $^{2}$

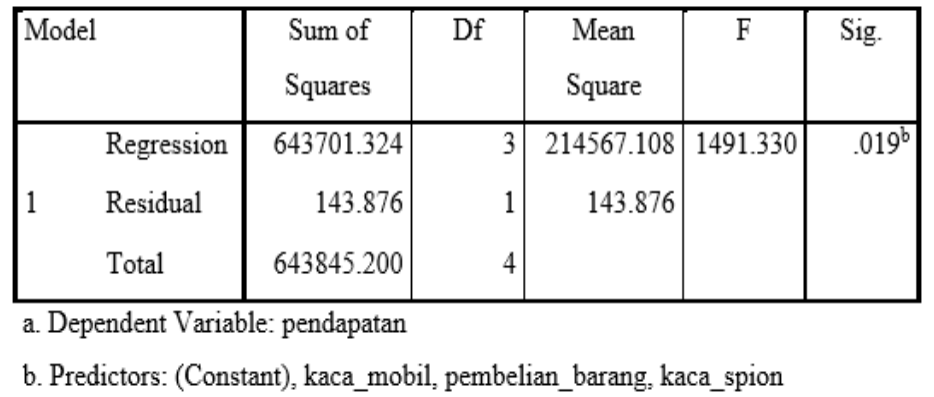

Tabel Annova di atas adalah salah satu untuk menguji ketepatan model. Apakah variabel bebas secara simultan (bersama-sama) mempengaruhi variabel terikat. Maka digunkan uji F.

Hipotesis :

1. Jika nilai sig $<0,05$ atau $\mathrm{F}$ hitung $>\mathrm{f}$ tabel maka, terdapat pegaruh variabel $\mathrm{X}$ secara simultan terhadap variabel $\mathrm{Y}$.

2. Jika nilai sig >0,05 atau $\mathrm{F}$ hitung $<\mathrm{f}$ tabel maka, tidak terdapat pegaruh variabel $\mathrm{X}$ secara simultan terhadap variabel Y.

\subsubsection{Koefisien Determinasi $\left(\mathbf{U} j i \mathbf{R}^{2}\right.$ )}

Tabel 6. Analisis Koefisien Determinasi

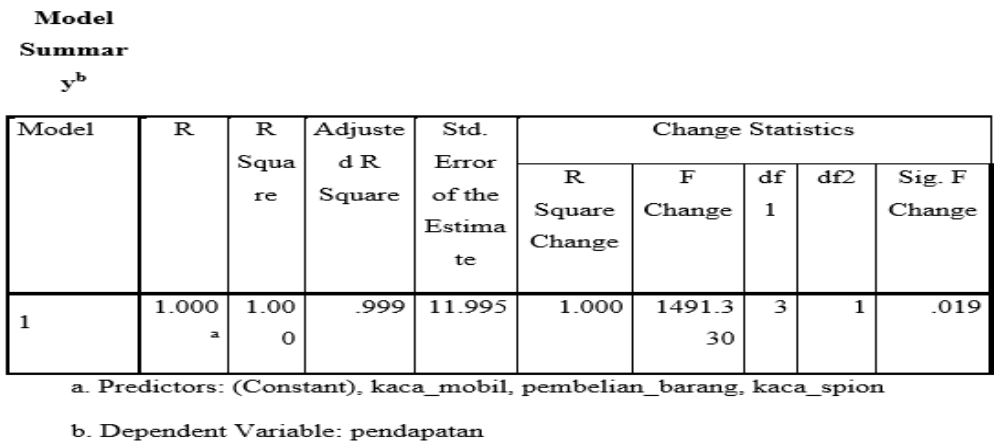


Dari tabel diatas nilai koefisien determinasi dapat diukur oleh nilai R Square atau Adjusted R-Square. R-Square digunakan pada saat variabel bebas hanya satu saja (biasa disebut dengan Regresi Linier Sederhana), sedangkan Adjusted R-Square digunakan pada saat variabel bebas lebih dari satu. Dalam menghitung nilai koefisien determinasi penulis lebih senang menggunakan RSquare daripada Adjusted RSquare, walaupun variabel bebas lebih dari satu.

\subsection{Implementasi Sistem}

Implementasi sistem merupakan hasil dari analisis kebutuhan dan design sistem yang telah diuraikan dalam bentuk model UML ( Unified Modeling Language ). Berikut ini beberapa antarmuka hasil implementasi sitem.

\subsubsection{Tampilan Login}

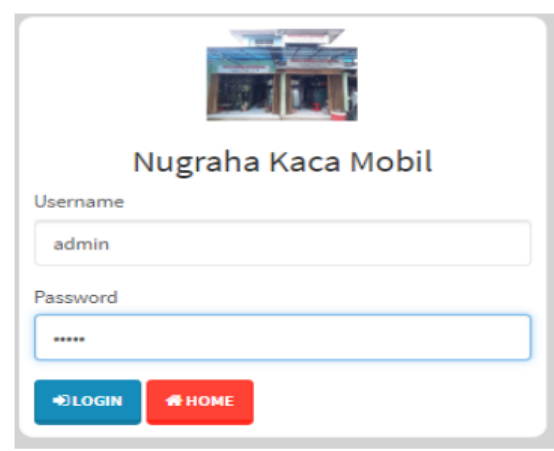

Gambar 5. Tampilan login admin

Pada tampilan login diatas merupakan halaman login mempunyai yang mempunyai form username dan admin, sehingga admin dapat mengakses dan mengelola system tersebut.

\subsubsection{Tampilan Penjualan Barang}

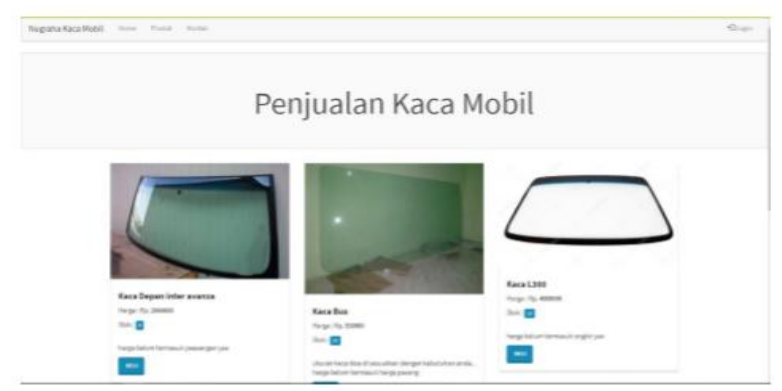

Gambar 6. Tampilan penjualan barang

Pada gambar diatas adalah halaman yang menampilkan data barang- barang penjualan, dimana customer dapat memilih dan melihat info barang sesuai dengan kebutuhan.

\subsubsection{Tampilan Proses Perhitungan Hasil Prediksi}

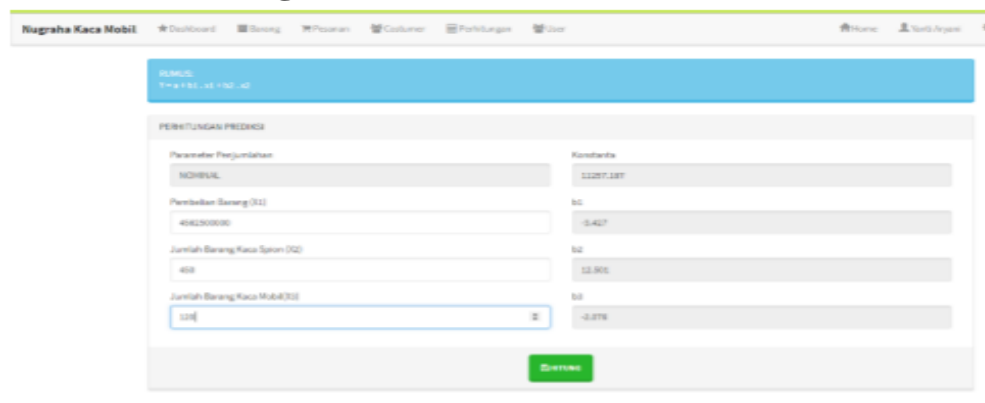

Gambar 7. Tampilan perhitungan hasil prediksi 
Pada gambar diatas merupakan tampilan perhitungan prediksi dimana admin dapat melihat prediksi pendapatan di tahun yang akan datang aakah meningkat atau menurun.

\subsection{Pembahasan}

\subsubsection{Data Hasil Penjualan}

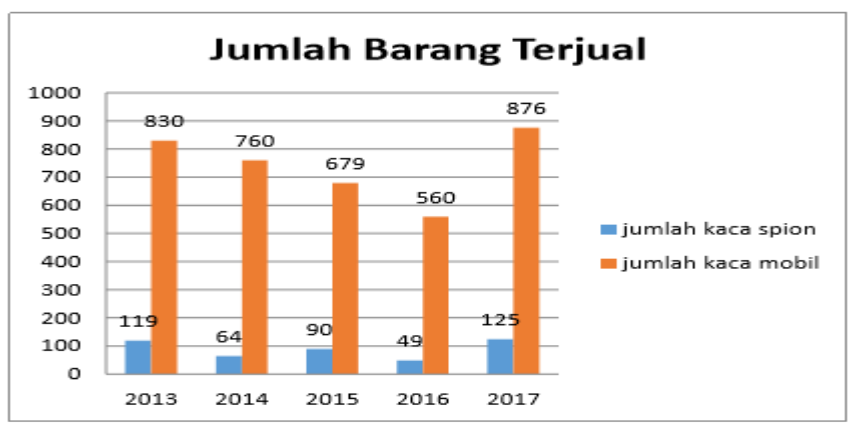

Gambar 8. Grafik Data Penjualan Barang

Grafik diatas menggambarkan data hasil penjualan dari jumlah penjualan kaca spion dan kacca mobil. Penjualan pada kaca mobil stiap tahun nya lebih unggul di bandingkan dengan penjualan jenis barang kaca spion.

\subsubsection{Data Hasil Pendapatan dan Pembelian}

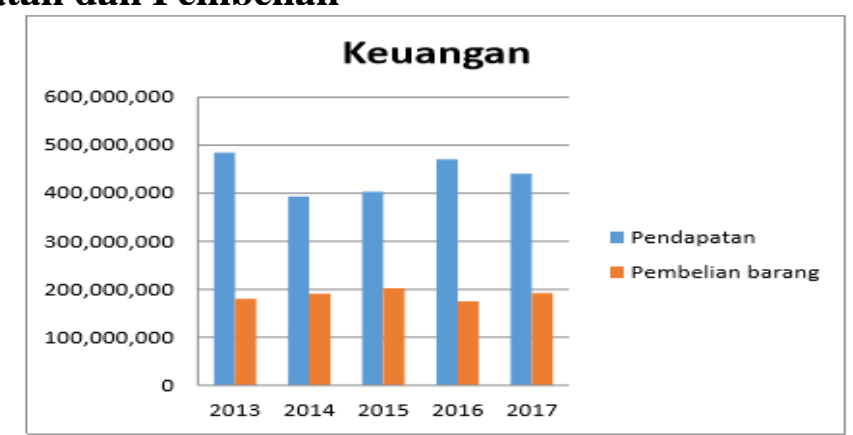

Gambar 9. Grafik Pendapatan dan Penjualan Barang

Pada gambar di atas menjelaskan bahwa hasil pendapatan dan pembelian barang pada CV. Kaca Mobil Nugraha tidak menentu atau tidak sinkron dengan data pembelian barang. Sehingga hal seperti ini mengakibatkan terjadinya penumpukan barang di gudang dan pendapatan pun mengalami penurunan karena tidak tepatnya dalam pembelian barang.

\subsubsection{Proses Regresi}

Berdasarkan hasil pengujian pada tabel coefficients, pada model regresi yang terbentuk, dapat diinterpretasikan hasil sebagai berikut :

$$
\mathrm{Y}=11257,187-3,427(\mathrm{X} 1)+12,501(\mathrm{X} 2)-2,076(\mathrm{X} 3)
$$

- $\quad$ Konstanta sebesar 11257,187 artinya jika X1,X2dan X3 = 0 maka $Y=11257,187$

- Coefficients (X1) sebesar - 3,427 artinya setiap 1 unit niali X1 akan berkurangnya nilai Y sebesar 3,427 . Nilai koefisien regresi yang negative menunjukkan bahwa pembelian barang (X1) terhadap volume penjualan (Y) berpengaruh negative.

- Coefficients (X2) sebesar 12,501 artinya setiap 1 unit nilai X2 akan menambah nilai Y sebesar 12,501. Nilai koefisien regresi yang positif menunjukkan bahwa jumlah barang terjual pada kaca spion (X1) terhadap volume penjualan (Y) berpengaruh positif. 
- Coefficients (X3) sebesar - 2,076 artinya setiap 1 unit niali X3 akan berkurangnya nilai Y sebesar 2,076. Nilai koefisien regresi yang negative menunjukkan bahwa jumlah barang terjual pada kaca mobil (X3) terhadap volume penjualan (Y) berpengaruh negative.

\subsubsection{Proses Uji T, F dan R2}

\subsubsection{Uji T}

Variabel pembelian barang memperoleh hasil t signifikan $0,011<0.05$, sehingga disimpulkan bahwa pembelian barang berpengaruh positif dan signifikan terhadap hasil pendapatan pada perusahaan CV. Kaca Mobil Nugraha. Artinya apabila pembelian barang. Maka asumsinya adalah variabel X1 berpengaruh [arah negatif] terhadap $\mathrm{Y}$, atau semakin meningkatnya X maka Y mengalami pernurunan.

Variabel pembelian barang memperoleh hasil t signifikan $0,018<0.05$, sehingga disimpulkan bahwa jumlah barang terjual dari kaca spion berpengaruh positif dan signifikan terhadap hasil pendapatan pada perusahaan CV. Kaca Mobil Nugraha. Artinya apabila pembelian barang semakin banyak maka pendapatan juga akan meningkat, begitu pula sebaliknya.

Variabel pembelian barang memperoleh hasil t signifikan $0,028<0.05$, sehingga disimpulkan bahwa jumlah barang terjual dari kaca mobil berpengaruh positif dan signifikan terhadap hasil pendapatan pada perusahaan CV. Kaca Mobil Nugraha. Artinya apabila pembelian barang semakin banyak maka pendapatan juga akan meningkat, begitu pula sebaliknya.

\subsubsection{Uji F}

Berdasarkan hasil pengujian hipotesis, variabel pembelian barang, jumlah barang terjual kaca spion dan kaca mobil yang secara bersamasama berpengaruh positif dan signifikan terhadap hasil pendapatan perusahaan pada CV. Kaca Mobil Nugraha, terdapat pengaruh positif dan signifikan. Hal bisa dilihat dari hasil SPSS yang diperoleh nilai signifikan 0,019<0,05, dengan demikian dapat disimpulkan bahwa variabel X1, X2, dan X3 diterima artinya secara bersamaan (similtan) pembelian barang, jumlah kaca spion, dan jumlah kaca mobil yang tejual berpengaruh signifikan terhadap pendapatan perusahaan CV.Kaca Mobil Nugraha. Sementara untuk melihat berapa persen pengaruh tersebut, dapat di jelaskan pada pembahasan Uji Koefisien Determinasi (R2).

\subsubsection{Uji $\mathbf{R}^{2}$}

Dari hasil output model summary, diketahui nilai koefisien determinasi (R square) sebesar 1,000 besarnya angka koefisien determinasi ( $R$ square) 1,000 sama dengan 100,0\%. Angka tersebut mengandung arti bahwa pembelian barang, jumlah kaca spion, dan jumlah kaca mobil yang tejual terhadap pendapatan berpengaruh sebesar 1,000 ini berarti semua variabel yang di teliti sangat berbengaruh .besarnya nilai koefisien determinasi atau $\mathrm{R}$ square hanya antara $0-1$. Sementara jika di jumpai nilai R square bernilai minus (-), maka dapat dikatakan bahwa tidak terdapat pengaruh $\mathrm{X}$ terhadap Y. Semakin kecil nilai koefisien determinasi ( $\mathrm{R}$ square), maka ini artinya pengaruh variabel bebas terhadap variabel terikat semakin lemah. Sebaliknya, jika nilai R Square semakin mendekati 1, maka pengaruh tersebut akan semakin kuat.

\subsection{Hasil Pengujian Sistem}

Untuk memastikan bahwa perangkat lunak yang dibuat memiliki standar minimal kualitas, maka salah satu metoda untuk pengukuran kualitas perangkat lunak secara kuantitatif adalah metoda SQA (Software Quality Assurance). 
JURSISTEKNI (Jurnal Sistem Informasi dan Teknologi Informasi) Vol 2, No. 2, Mei 2020: Hal 39 - 51

ISSN. P: 2715-1875, E: 2715-1883

Tabel 7. Metric of Software Quality Assurance (SQA)

\begin{tabular}{|r|l|l|c|}
\hline \multicolumn{1}{|c|}{ No } & \multicolumn{1}{|c|}{ Metrik } & Deskripsi & Bobot \\
\hline 1 & Auditability & Memenuhi standard atau tidak & 0.125 \\
\hline 2 & Accuracy & Keakuratan komputasi & 0.125 \\
\hline 3 & Completeness & Kelengkapan & 0.125 \\
\hline 4 & Error Tolernce & Toleransi terhadap kesalahan & 0.125 \\
\hline 5 & Expandability & Pengembangan perangkat lunak & 0.125 \\
\hline 6 & Operability & Kemudahan untuk dioperasikan & 0.125 \\
\hline 7 & Simplicity & Kemudahan untuk di pahami & 0.125 \\
\hline 8 & Training & $\begin{array}{l}\text { Kemudahan pembelajaran fasilitas } \\
\text { Help }\end{array}$ & 0.125 \\
& & & \\
\hline
\end{tabular}

Ada 8 buah kriteria yang dapat digunakan untuk mengukur kualitas sebuah perangkat lunak secara kuantitatif. Seperti terlihat pada tabel diatas.

Tabel 6. Skor metrik

\begin{tabular}{|c|r|r|r|r|r|r|r|r|r|}
\hline \multirow{2}{*}{ Audience } & \multicolumn{7}{|c|}{ Skor Metrik } & \multirow{2}{*}{ Skor } \\
\cline { 2 - 9 } & \multicolumn{1}{|c|}{$\mathbf{1}$} & $\mathbf{2}$ & $\mathbf{3}$ & $\mathbf{4}$ & $\mathbf{5}$ & $\mathbf{6}$ & $\mathbf{7}$ & $\mathbf{3}$ & \\
\hline$\# 1$ & 79 & 80 & 82 & 80 & 87 & 78 & 86 & 83 & 81.875 \\
\hline$\# 2$ & 78 & 82 & 85 & 82 & 81 & 87 & 79 & 85 & 82.375 \\
\hline$\# 3$ & 80 & 82 & 81 & 82 & 85 & 79 & 86 & 85 & 82.5 \\
\hline$\# 4$ & 86 & 79 & 85 & 82 & 79 & 88 & 80 & 83 & 82.75 \\
\hline$\# 5$ & 79 & 86 & 86 & 82 & 87 & 90 & 79 & 89 & 84 \\
\hline
\end{tabular}

Pada tabel 6 diatas merupakan hasil angket yang dilakukan pada 5 orang pengamat yang berperan sebagi user dan diambil secara acak. Skor $=\langle 80,4\rangle * 0.125+\langle 80,6,4\rangle * 0.125+\langle 83,8\rangle * 0.125+$ $\langle 81,6\rangle * 0.125+\langle 83,8\rangle * 0.125+\langle 84,4\rangle * 0.125+\langle 82\rangle * 0.125+\langle 85\rangle * 0.125$ Skor rata-rata yang dihasilkan adalah 82,7 , sedangkan nilai optimal untuk sebuah perangkat lunak yang memenuhi standar kualitas berdasarkan uji SQA adalah 80 .

\section{KESIMPULAN}

Berdasarkan hasil penelitian dan pembahasan yang berkaitan dengan pengaruh pembelian barang, jumlah barang terjual kaca spion dan kaca mobil terhadap pendapatan perusahaan pada CV. Kaca Mobil Nugraha, hasil hipotesis pertama diperoleh persamaan regresi yaitu $\mathrm{Y}=11257,187-3,427(\mathrm{X} 1)+$ 12,501(X2 2,076(X3) Dalam hal ini saya mengambil hasil uji dari nilai signifikan 0,05 dan menunjukkan bahwa nilai signifikan dilihat bahwa dari variabel bebas (X1) $0,011<0,05$, berpengaruh signifikan terhadap variabel Y. Selanjutnya untuk variabel bebas (X2) 0,018< 0,05, yang di hasilkan nilai signifikansi 0,05 sehingga dapat disimpulkan bahwa variabel X2 tersebut berpengaruh terhadap pendapatan (Y). dan untuk variabel bebas (X3) 0,028<0,05, hal ini juga dapat dismipulkan bahwa variabel bebas X3 berpengaruh terhadap pendapatan. Dalam hal ini berarti hasil uji secara individual variabel pembelian barang (X1), jumlah barang terjual kaca spion (X2) dan jumlah barang kaca mobil (X3) berpengaruh signifikan terhadap hasil penjualan perusahaan CV. Kaca Mobil Nugraha. Hasil penelitian secara simultan atau bersama-sama dilihat bahwa pembelian barang, jumlah barang terjual kaca spion dan jumlah kaca mobil memperoleh hasil signifikan $0,019<0,05$, sehingga disimpulkan bahwa 
variabel yang di teliti berpengaruh positif dan signifikan terhadap pendapatan perusahaan CV. Kaca Mobil Nugraha. Hal ini berarti jika dari variabel tersebut ada yang bernilai negative maka akan mengalami penurunan terhadap pendapatan perusahaan. Interface system yang di buat menghasilkan skor rata-rata yang dihasilkan adalah 82,7, berdasarkan uji Metric of Software Quality Assurance (SQA). Sehingga dapat disimpulkan bahwa interface yang dibuat pada penelitian ini memenuhi standar kualitas.dan Sistem yang dibangun ini dapat mempermudah pemilik perusahaan untuk melihat hasil prediksi pendapatan, sistem ini dapat meminimalisir kerugian, memberikan informasi yang cepat dan akurat tentang prediksi pendapatan.

\section{DAFTAR PUSTAKA}

[1] A.H Saputra,Tarno \& B. Warsito. "Analisa Data Runtun Waktu dengan Metode Adaptive NeuroFuzzy Inference System (ANFIS)”. Jurnal Gaussian, Vol. 1, No. 1, pp. 31-40, 2012.

[2] M.A. Boyacioglu, \& D. Avci. " An Adaptive NetworkBased Fuzzy Inference System (ANFIS) for The Prediction of Stock Market Return : The Case of Istanbul Stock Exchange. Elsevier”, Vol. 37, pp.79087912, 2010.

[3] Syukriyadin \& R. Syahputra. "Prakiraan Beban Listrik Jangka Pendek Kota Banda Aceh Berbasis Logika Fuzzy", Jurnal Rekayasa Elektrika, Vol. 1, No. 1, pp. 46-51, 2012.

[4] Prasetyo, Eko. "Data mining Konsep dan Aplikasi menggunakan Matlab", ANDI, Yogyakarta, 177, 2012.

[5]. Y Liu, YF Zheng. "FS_SFS:Anovel feature selection method for Support Vector Machines", The Ohio State University, Columbus OH 43210, USA. Pattern recognition, 2012.

[6]. Neneng, S. "Seleksi Variabel dalam Analisis Regresi Multivariat Multiple", Stap Jurusan Statistika FMIPA UNPAD, Seminar Nasional dan Pendidikan Matematiaka, ISBN: 978-979- 16353-3-2, 2009.

[7] Ratih Dewanti dan Ginda Sihombing. " Analisis Pendapatan Usaha Peternakan Ayam Buras (Studi Kasus di Kecamatan Tegalombo, Kabupaten Pacitan)”. Buletin Peternakan Vol. 36(1): 48-56, Februari 2012.

[8] Hutami, Resti \& Erna Zuni Astuti. "Implementasi Metode K-Nearest Neighbor Untuk Prediksi Penjualan Furniture pada CV. Octo Agung Jepara". Semarang: Universitas Dian Nuswantoro, 2016.

[9] Muslih, Muhamad, et.al. "Marketing Strategy with Linier Regression to the Interest New Students". International Conference Computing and Design, IIUM Malaysia, 2017. 